\title{
PAŃSTWOWOŚĆ KAZACHSKA: HISTORIA I RZECZYWISTOŚĆ. PRZYCZYNEK DO TEORII PAŃSTWA'
}

\section{Wprowadzenie}

W Republice Kazachstanu w ostatnich miesiącach w środkach masowego przekazu i w internecie szeroko toczy się dyskusja się nad zagadnieniem państwowości kazachskiej². Zdaniem prezydenta Federacji Rosyjskiej, prezydent N. Nazarbajew jest wielkim przywódcą, bowiem „Dokonał on unikalnej rzeczy. Stworzył państwo na terytorium, na którym nigdy wcześniej nie istniało państwo. Kazachowie nigdy nie mieli państwowości. On ją stworzył”. Wypowiedź ta wywołała w Kazachstanie ostry sprzeciw i reakcję przede wszystkim na portalach społecznościowych. Post na Twitterze o rozpoczęciu akcji „Wyślij Putinowi podręcznik historii” zebrał setki retwittów. Po wspomnianej wypowiedzi w Kazachstanie, szczególnie w środowiskach naukowych i opiniotwórczych, zaczęto otwarcie mówić o tym, iż prawdopodobnie znów odżyją spory dotyczące przynależności państwowej północnych terytoriów Kazachstanu, zamieszkiwanych w znacznym stopniu przez ludność rosyjskojęzyczną. Stanowisko prezydenta Rosji poparli niektórzy przedstawiciele środowiska nacjonalistyczno-szowinistycznego, a ich wypowiedzi miały charakter ekstremistyczny i budzący nienawiść etniczną. Niektórzy z nich otwarcie występowali przeciwko narodowi kazachskiemu, przykładowo W. Żyrinowski w wywiadzie dla radia Echo Moskwy otwarcie oświadczył: „Po Ukrainie zabierzemy Kazachstan, ponieważ w ostatnim okresie nasilają się »nastroje antyrosyjskie« wśród Kazachów”. Dla historyków i politologów wypowiedzi W. Putina i innych rosyjskich nacjonalistów (E. Limonowa,

1 Rosyjskojęzyczną część tekstu na język polski przetłumaczyła Anna Romiszewska.

2 Problem został dosłownie wyrażony na ogólnorosyjskim Forum Młodzieży Seliger-2014 (obwód nowogrodzki, Rosja), na którym prezydent W. Putin stwierdził, iż Kazachstan nigdy nie posiadał państwowości, a państwo to pod względem liczby ludności jest 10-krotnie mniejsze od FR. Słowa te zostały wypowiedziane w sytuacji, w której władza wykonawcza w Astanie (prezydent N. Nazarbajew na spotkaniu w Mińsku) wyraziła poparcie dla rządu w Kijowie, dążącego do stowarzyszenia z Unią Europejską. Stanowi jednocześnie wyraz ofensywy propagandowej władz rosyjskich dążących do zdezawuowania tradycji państwowych i narodowych wszystkich państw powstałych po rozpadzie ZSRR, w tym Ukrainy i Kazachstanu. 
W. Żyrinowskiego) są przede wszystkim oznaką rosyjskiej „agresji propagandowej”, a ich konstatacje oparte są na powierzchownej wiedzy historycznej i teoretycznej z zakresu nauki o państwie.

Z powyższych względów zasadniczym celem autorów artykułu jest upowszechnienie udokumentowanej, rzetelnej wiedzy na temat niektórych przejawów wielowiekowej państwowości Kazachów, wiedzy odległej od prób mistyfikacji i fałszowania wydarzeń oraz procesów historycznych w Azji Środkowej. Jednocześnie celem jest również przedstawienie ustaleń teoretycznych na gruncie nauki o państwie, które określają genezę i cechy charakterystyczne organizmów państwowych powstałych na rozległych terenach Azji Środkowej w różnych okresach historii cywilizacji.

\section{Geneza i źródła państwowości kazachskiej}

Określenie istoty i ujęcia państwa, etymologia samego terminu, geneza, charakterystyczne cechy ewolucji państwa, formy i funkcje oraz reżimy polityczne, charakter władzy, normy społeczne i inne aspekty były i są przedmiotem zainteresowania badaczy w wielu państwach ${ }^{3}$. Przede wszystkim należy zauważyć, że słowo państwowość w literaturze politycznej używane jest często jako synonim państwa. Według niektórych badaczy państwo to niezależna, scentralizowana organizacja społeczno-polityczna mająca za zadanie regulowanie stosunków społecznych. Istnieje ona w złożonym, stratyfikowanym społeczeństwie, zajmującym określone terytorium i złożonym z dwóch podstawowych warstw: rządzących i rządzonych. Stosunki między tymi warstwami charakteryzują się polityczną władzą pierwszych i obowiązkami, np. podatkowymi, drugich. Stosunki te zostały uprawomocnione podzielaną przynajmniej przez część społeczeństwa ideologią, u której podstaw leży zasada wzajemności.

W polskiej literaturze przedmiotu wskazuje się, że „państwo jest terytorialną i polityczną instytucją, która wykorzystując system prawny, gospodarczy i układ stosunków międzynarodowych, efektywnie tworzy optymalne warunki rozwoju cywilizacyjnego danego społeczeństwa”. Powszechnie przyjmuje się, że prototypy „państwa”

3 Por. D. Held, Political Theory and the Modern State, Polity Press, Cambridge 1989; P.Q. Hirst, The Pluralist Theory of the State, Routledge, London 1989; G. Poggi, The State, Its Nature, Development and Prospects, Polity Press, Cambridge 1990; R. Lachmann, States and Power, Polity Press, Cambridge 2010; Wspótczesne państwo w teorii i praktyce, red. J. Oniszczuk, Oficyna Wydawnicza SGH, Warszawa 2011.

4 H.J.M. Claessen, State, w: Encyclopedia of Cultural Anthropology, Vol. IV, red. D. Levinson, M. Ember, Henry Holt\&Co., New York 1996, s. 1255.

5 J. Osiński, Niezbędność państwa $w$ dobie globalizacji oraz jego współczesne modele, w: Współczesne państwo $w$ teorii i praktyce, red. J. Oniszczuk, Oficyna Wydawnicza SGH, Warszawa 2008, s. 416. 
i pierwsze formy instytucji scentralizowanej terytorialnie władzy powstały w epoce późnego kamienia, neolitu i brązu. Tendencje te były charakterystyczne również dla terytorium kazachskiego, gdzie na powszechnie przyjęte normy społeczne składały się zwyczaje, tradycje i obrzędy starożytnych mieszkańców tego regionu. W epoce brązu na terytorium Kazachstanu pojawiły się i istniały związki plemienne. Świadczą o tym kultury archeologiczne, m.in. ałakulska, pietrowska, fiodorowska, kolsajska, begazy-dandybajewska, nur tajska czy dongalska. Prawdopodobnie w tym okresie pojawiły się pierwsze zalążki państwa i państwowości. Jednak brak konkretnych źródeł pisanych uniemożliwia do tej pory dokładne określenie charakteru organizacji państwowej wspomnianych plemion.

Od czasów starożytnych terytorium kazachskie było zamieszkiwane przez koczownicze i półkoczownicze plemiona, trudniące się pasterską hodowlą bydła, które już wówczas tworzyły pierwsze organizmy państwowe, a za najstarsze z nich można uznać związki plemienne wczesnych koczowników. Powstały twory państwowe plemion Saków, Wusunów ${ }^{6}$, Kangły (Kangcha, Kangju K'ang-Kii), a największym z nich było imperium Hunów.

Kazachska nauka historii stoi od dawna na stanowisku, że pierwsze związki państw i państwa, wspominane w starożytnych źródłach pisanych, pojawiły się na terytorium Kazachstanu w epoce wczesnego żelaza. Na przykład w Historii Herodota są wzmianki o kilku plemionach, na których czele stali władcy, zamieszkujących terytorium Azji Środkowej: Sakach, Sarmatach (Sawronaci) i Massagetach (Hunowie). Herodot i inni starożytni autorzy nazywali ich Scytami Azjatyckimi, starożytni Chińczycy - Se, a Persowie - Sakā. W starożytnych tekstach perskich Sakowie dzieleni są na cztery grupy: 1) Sakāhaumavargā - Sakowie, którzy piją napój haoma, 2) Sakātigraxaudā - Sakowie, którzy noszą stożkowate nakrycia głowy, 3) Sakāparadraya - Sakowie, którzy mieszkają za morzem, 4) Sakā para Sugdam - Sakowie, którzy mieszkają za Sogdianą ${ }^{7}$ W celu rozróżnienia Saków i Massagetów od Scytów z północnych ziem basenu Morza Czarnego niektórzy uczeni używają terminu „kultura kręgu sakijsko-massageckiego". Na czele Saków stał król, a społeczeństwo składało się z trzech grup: wojowników, kapłanów i ludu. Niewolnicy byli wykorzystywani w pracach domowych. Władcy i wodzowie pochodzili z grupy wojowników. Znane są imiona sakijsko-massageckich królowych, jak Zarina i Tomirys. Naznaczenie królowych było wyrazem woli ludu (plemienia), co wskazuje na pewien element równouprawnienia kobiet i mężczyzn w tamtym społeczeństwie. Mimo że król miał swoje przywileje,

6 Terminy: „Wusunowie”, „Ujsunowie” i „Usunowie” używane są w polskiej literaturze zamiennie i dotyczą tego samego plemienia. Podkreśla się ich związek z plemieniem Saków. Por. T. Nagrodzka-Majchrzyk, Geneza miast u dawnych ludów tureckich (VII-XII w.), Ossolineum, Warszawa 1978.

7 Por. К. Сосанов, История Казахстана, Ол-Жас Баспасы, Алматы 2007. 
na przykład wyorywał pierwszą bruzdę na polu wiosną, rozdzielał łupy wojenne między wojowników, przewodniczył zebraniu członków plemienia, prowadził politykę wewnętrzną i zagraniczną, to społeczeństwo było przywiązane do demokracji wojennej. Niektórzy kazachscy uczeni (A.T. Toleybayev i in.), którzy badali monumentalne „królewskie piramidy” (Shilitkin i in.) uważają, że państwowość u Saków wytworzyła się już w pierwszych wiekach wczesnego żelaza.

W III-II w. p.n.e. plemiona Wusunów utworzyły państwo, które w literaturze chińskiej nazywane jest Wusun-go (wusun jest nazwą plemienia, a go oznacza państwo). Część Saków została zepchnięta z Żetysu (południowo-wschodni Kazachstan), a część zasymilowała się z Wusunami. Świadczą o tym przede wszystkim ślady archeologiczne. Główne terytorium Wusunów rozciągało się w dolinie rzeki Ili, a zachodnią granicę wyznaczały rzeki Czu i Tałas, gdzie Wusunowie graniczyli z plemieniem $\mathrm{Kangły}^{8}$. Z chińskich źródeł wiadomo, iż w I w. p.n.e. populacja Wusunów sięgała 630 tys. osób. Na czele państwa stał władca, noszący tytuł kunbi (kun - słońce; bi - bek, władca, ten, kto rządzi, sędzia), a w chińskiej transkrypcji - gunmo. Chińskie źródła informują, że stolicą Wusunów było miasto Cziguczen (Czuczu-gen) ${ }^{9}$, a tron był dziedziczny. Państwo zostało podzielone na dwa skrzydła: Wielki kunbi i Mały kunbi. Poza władcą w państwie istniało osiem kategorii urzędników. Pomocnik władcy nosił tytuł dugłu i faktycznie sprawował funkcję głowy władzy wykonawczej. Niżej w hierarchii znajdowało się dwóch dowódców wojskowych i trzech urzędników zarządzających okręgami. Pomocnikami dowódców byli urzędnicy o tytule dartu. Oprócz nich byli także urzędnicy odpowiedzialni za stawianie obozowiska kunbi, zbieranie podatków, przestrzeganie prawa itp. Wusunowie weszli później w skład społeczeństwa kazachskiego, które składa się z trzech żuzów (związków plemion): Wielkiego (w rosyjskiej literaturze zwanego „Starszym”, na co miała wpływ rosyjska polityka kolonizacyjna, która nie chciała „wywyższać” części Kazachów), Średni i Młodszy. Do tej pory wśród Kazachów funkcjonuje wyrażenie: „Wielki Żuz, to jest Wusun”.

W zbliżonym czasie na południu Kazachstanu i na sąsiadujących terenach plemiona Kangły (Kangcha, Kangju, K’ang-chii) utworzyły swoje państwo. W Opowieści o zachodnim kraju w Historii starszego domu Han o państwie Kangju mówi się następująco: „Władca Kangju przebywa w krainie Luen w mieście Bitan [...] Ludność składa się z 120000 rodzin, 600000 dusz; wojsko z 120000 ludzi”. Na zachód od Kangju zamieszkiwały plemiona sarmacko-alańskie, a na wschód Wusunowie. Źródła chińskie opisują gospodarkę, byt i organizację państwa Kangju. Na czele stał „wielki chan”, wspierany przez kilku doradców i pomocników. Plemionami rządzili

8 Ю.А. Зуев, Ранние тюрки: очерки истории и идеологии, Дайк-Пресс, Алматы 2002.

9 Por. http://pl.scribd.com/doc/145086514/Kondratow-Aleksander-Tajemnice-trzech-oceanow\#scribd 
wodzowie, a ich władza była dziedziczona z ojca na syna. Państwo Kangju było podzielone na 5 części, a na czele każdej z nich stał Mały chan ${ }^{10}$. Możnowładztwo i dowódcy wojskowi mieli niewolników, pochodzących z grupy jeńców wojennych. Do dziś wśród Kazachów żyje plemię Kanły, wywodzące się ze starożytnego Kangju. Kazachska mądrość głosi: „Bez Kangły nie można naznaczyć chana”, co wskazuje na znaczenie tego plemienia w historii państwa kazachskiego.

W IV-III w p.n.e. w Azji Środkowej istniał związek plemienny Hunów. Czasami nazywa się ten związek konfederacją Hunów, zważywszy na to, iż w jej skład wchodziły różne starożytne plemiona. Hunowie w II w. utworzyli na terytorium wschodniego Kazachstanu i Żetysu (południowo-wschodni Kazachstan) państwo Yueban, które przetrwało do V w. Część plemion Kazachstanu przeniosła się na zachód, rozpoczynając wielką wędrówkę ludów. Na czele Hunów stał shanyu. Hunowie mieli złożony aparat zarządzania. Ludność była opodatkowana, przeprowadzano też jej powszechny spis. Niższą warstwę społeczną stanowili niewolnicy - jeńcy wojenni. Organizacja państwa Hunów uwzględniała aspekty wojskowe - państwo było podzielone na trzy skrzydła: prawe, centralne i lewe ${ }^{11}$. Najważniejszymi osobami w państwie po shanyu byli tumenbasowie, którzy dowodzili 10-tysięcznymi oddziałami i byli jednocześnie wodzami plemion. Regularnie trzy razy w roku wodzowie - dowódcy wojskowi spotykali się z shanyu w celu omówienia spraw państwowych. Społeczność Hunów miała charakter patriarchalny. Władza była dziedziczna z ojca na syna. Wykształcił się system prawny i zasady postępowania. Źródła archeologiczne i pisane świadczą o tym, że związki terytorialne Wusunów, Kangły i Hunów mimo ich koczowniczego charakteru osiągnęły poziom państwowości. Starożytni Chińczycy i Persowie opisują ich organizację jako państwo ${ }^{12}$.

W okresie średniowiecza wraz z rozwojem pasterstwa koczowniczego bydła i gospodarki wcześniejsze instytucje polityczne okrzepły, a miejsce wczesnych koczowników i ich tworów państwowych zajmują bardziej rozwinięte państwa jak Kaganat Turecki (552-603) i jego następcy: Kaganat Zachodnioturecki (603-704), Kaganat Turgeszów (704-756), Kaganat Karłuków (756-940), państwo tureckich Oguzów (750-1055). Kaganat Turecki był pierwszym państwem, które zajmowało ziemie europejskie i azjatyckie. Głową państwa była kagan (chan). Miał on silną władzę, mianował wielmożów i wyznaczał dowódców wojskowych. Jego zastępcą był jabgu (żabgu). Następca tronu nosił tytuł tegni, a wśród innych wysokich tytułów należy

10 Д.С. Байгунаков, Историография истории древнего Казахстана, Автореферат докторской диссертации, Алматы 2010.

11 Ibidem.

12 Ibidem; Г.Л. Файзрахманов, Древние тюрки Сибири и Центральной Азии, Мастер Лайн, Казан 2000. 
wymienić szada i eltebera. Funkcje sądownicze wypełniali bujurukowie i tarchanowie. Źródła podają więcej szczegółów na temat organizacji Kaganatu Zachodniotureckiego. Na jego czele stał kagan (chan) wybierany spośród członków należących do panującego rodu turk-aszyna. Pełnił on kilka funkcji: władcy, głównodowodzącego wojskiem, właściciela wszystkich ziem i najwyższego sędzi. Następcy tronu nazywali się tagni. Wyższych urzędników państwowych - żabgu (jabgu), szata, eltebera - naznaczano spośród krewnych władcy, a zadaniem ich była pomoc kaganowi w rządzeniu. Podobnie jak w Kaganacie Tureckim funkcje sądownicze sprawowali bujrukowie i tarchanowie. Na podbitych ziemiach kagan ustanawiał swoich namiestników - tudunów. Na czele rodów i plemion stali bekowie, a prosty lud nazywano kara budun. Niewolnicy (tatowie) byli wykorzystywani przy pracach domowych. Natomiast Kaganat Karłuków charakteryzował się wojskowo-administracyjnym systemem sprawowania rządów. Każde z plemion miało swoje ziemie, a aparat urzędniczy był bardzo zbliżony do tych we wspominanych wcześniej państwach. Głową państwa Oguzów był żagbu, a władza była dziedziczna. Następców tronu nazywano inałami, a ich wychowaniem zajmowali się atabekowie. Zastępcą żagbu był kul-erkin, a dowódców wojskowych zwano subaszi.

W państwie Kimaków i Kipczaków także istniały wyżej wspomniane tytuły, choć niektóre urzędy nosiły inne nazwy. Niektóre z wczesnośredniowiecznych tworów państwowych zajmowały terytorium nie tylko Kazachstanu, ale też Azji Środkowej ${ }^{13}$. Przyczyniły się one do rozwoju państwowości na terytorium Kazachstanu. W epoce średniowiecza na terytorium Kazachstanu powstawały państwa nie tylko koczowników i półkoczowników, ale także ludności prowadzącej osiadły i rolniczy tryb życia, zajmujące różne części terytorium Kazachstanu. Na przykład część autochtonicznych plemion południowo-wschodniego i południowego Kazachstanu założyło państwo Karachanidów i państwo Karakitajów w południowo-wschodnim Kazachstanie. W tworzeniu zarówno wspomnianych wcześniej, jak i innych państw brali udział potomkowie starożytnych mieszkańców tego regionu. Państwa XII-XII-wieczne miały też wpływ na rozwój instytucji politycznych na tym terenie. W XIII w. doszło do wydarzenia przełomowego w historii stepu koczowników - pojawiło się Imperium Mongolskie (Wielki Ułus Mongołów). Początek mongolskich podbojów i przyłączenie terytorium Kazachstanu do Imperium Mongolskiego rozpoczyna nowy etap rozwoju państwowości. Wraz z Mongołami osiedliły się także plemiona turkijskie (Najmanowie, Kereici, Dżalair i inne), które później stały się częścią społeczności kazachskiej.

13 Ibidem. 


\section{Ułus Dżocziego i powstanie Chanatu Kazachskiego}

Część Kazachstanu, np. Żetysu, dobrowolnie przyłączyła się do imperium Czyngis-chana. Po pochodach wojennych w Azji Środkowej i Kazachstanie Czyngis-chan podzielił swoje imperium pomiędzy czterech synów, każdemu z nich nadając ułus (dzielnicę). W skład ułusu jego starszego syna Dżocziego (ok. 1184/87-1225/27) weszła Syberia Zachodnia, step kipczacki (kazachski) i Chorezm. Dżoczi zmarł jeszcze za życia swego ojca. Jego dziedzicem został drugi syn Batu (1236-1255), który stał na czele mongolskiego najazdu na zachód, w którego czasie została podbita Bułgaria Wołżańsko-Kamska, step połowiecki, księstwa ruskie i niektóre z państw Europy Wschodniej. Na nowo podbitych terenach władzę objął Batu-chan i jego następcy. Batu swój ułus rozdzielił pomiędzy najbliższych krewnych, pozostawiając sobie zachodnią część ziem, tzw. Białą (Ak) Ordę. Jego brat Orda i jego następcy sprawowali władzę nad Syberią Zachodnią i Kazachstanem, a ułus ten nazywano Niebieską (Kok) Ordą. Istniało też kilka innych mniejszych części. Państwo stworzone przez Batu-chana w rosyjskiej i zachodnioeuropejskiej historiografii nazywane jest Złotą Ordą. Współczesne terytorium Kazachstanu nie tylko wchodziło w skład Złotej Ordy, ale stanowiło jej centrum.

Bez wątpienia Złota Orda (Ułus Dżocziego) odegrała istotną rolę w powstawaniu kazachskiej państwowości. Wiele elementów struktury władzy u Kazachów zostało zaczerpniętych z imperium Czyngis-chana lub od chanów Złotej Ordy, a część z nich kształtowano i doskonalono później. Mongolskie możnowładztwo na terytorium Kazachstanu z czasem łączyło się więzami krwi z możnowładztwem turkijskim i stopniowo asymilowało się ze środowiskiem turkijskim, a przede wszystkim kipczackim. Zgodnie z tradycyjnym modelem funkcjonowania państw koczowników Ułus Dżocziego po 1242 r. został podzielony na dwa skrzydła: prawe (zachodnie) i lewe (wschodnie). Za starsze uznawano skrzydło prawe - Ułus Batu-chana. Skrzydła dzieliły się na ułusy, w których sprawowali władzę inni synowie Dżocziego. Początkowo ułusów było 14, jednak z czasem ich liczba wzrosła. Namiestnikami chana na terenie ułusów byli ułusbecy. Zniszczone księstwa ruskie znalazły się w zależności wasalnej od Złotej Ordy. Książęta ruscy uznawali swą zależność wasalną, otrzymując $z$ rąk chanów tzw. Jarłyk,czyli potwierdzenie prawa do sprawowania władzy nad danym księstwem, uiszczali daniny, ale mimo to zachowywali oni stosunkową niezależność. Model funkcjonowania Złotej Ordy był bardzo zbliżony do modelu imperium Czyngis-chana. Państwo było uznawane za własność chańskiego rodu Dżuczidów. W celu rozstrzygnięcia spraw wagi państwowej był zwoływany Kurułtaj (ogólne zebranie możnowładztwa). Armią i stosunkami dyplomatycznymi z innymi 
państwami zajmował się beklerbek, który był także naczelnym ułusbekiem państwa. Na czele diuanu - centralnego organu władzy wykonawczej - stał wezyr. Sprawował on pieczę nad finansami, podatkami i sprawami wewnętrznymi. Miasta i ułusy podlegały darugom i baskakom, którzy także zbierali podatki i daniny. Najważniejsze urzędy zajmowali członkowie rodziny chana. Chan był głową państwa, a w jego rękach skupiona była władza absolutna. Prawe skrzydło Złotej Ordy w sumie dzieliło się na 70 drobniejszych części, także zwanych ułusami. Wszystkie z nich znajdowały się pod kontrolą chana ${ }^{14}$. Sturkizowani mongolscy władcy stymulowali rozwój handlu, kontaktów międzynarodowych, a także wprowadzili system pocztowy. Zostały nawiązane stosunki handlowe i kulturalne: po terytorium ułusów handlarze wiedli swe karawany, przybywały misje dyplomatyczne, podróżnicy, misjonarze. Władze zapewniały im bezpieczeństwo, a w państwie obowiązywało prawo Jasa, powstałe jeszcze za czasów Czyngis-chana. Dlatego też należy przyjąć, że państwowość kazachska ma wielowiekowe korzenie, a fundamentem współczesnego niepodległego Kazachstanu jest specyficzna państwowość, która była kształtowana przez wiele stuleci przez przodków współczesnych Kazachów.

Pod koniec XIV w. i na początku XV w. zatargi personalne i zewnętrzne naciski stopniowo doprowadziły do rozpadu Złotej Ordy. Niektóre ułusy z czasem przekształciły się w niezawisłe państwa. Dla przykładu na początku lat 20. XV w. powstał Chanat Syberyjski (Syberia Zachodnia), w 1428 r. - chanat Abułchaira (Abu al-Chajra) (Państwo Koczowniczych Uzbeków), zajmujący głównie centralne regiony Kazachstanu, na zachodnich terenach współczesnego Kazachstanu w latach 40. XV w. pojawiła się Orda Nogajska, a następnie Chanat Kazański (1438), Chanat Krymski (1441) i inne.

Jednym z państw, istniejącym na terenie wschodniego Deszt-i-Kipczak od połowy XIII w. do lat 30. XV w., była Ak Orda (Biała Orda). Kształt jej terytorium zmieniał się stopniowo, w miarę słabnięcia zależności od Złotej Ordy. W skład Ak Ordy wchodziła wschodnia część Ułusu Dżocziego (lewe skrzydło), obejmująca duży fragment współczesnego Kazachstanu, z wyjątkiem Żetysu, a od wschodu od rzeki Ural i na północ od Jeziora Aralskiego i rzeki Syr-darii. W XIV w. stolicą Ak Ordy zostało miasto Syganak. Ludność stanowiły plemiona turkijskojęzyczne. Obok Kipczaków mieszkali Najmanowie, Usunowie, Karłukowie, Kereici, Kongraci, Mangici, Argynowie i inne plemiona wchodzące w skład społeczeństwa kazachskiego. Pierwszym chanem Ak Ordy był sułtan Sasi Buka, a po jego śmierci kolejnym chanem został jego syn Irzan. Czasy ich panowania charakteryzują walki o oswobodzenie spod władzy Złotej Ordy Wschodniego Deszt-i-Kipczak. W drugiej połowie XIVw. i w pierwszej połowie

14 Г.А. Фёдоров-Давыдов, Общественный строй Золотой Ордь, МГУ, Москва 1973. 
$\mathrm{XV}$ w. chanowie Ak Ordy prowadzili wojny ze swymi potężnymi sąsiadami ${ }^{15}$. Niektórzy historycy, np. Z. Kinayatuly, uważają, że Ak Ordę należy uznać za jądro Chanatu Kazachskiego, bowiem plemiona i potomkowie władców związani byli przede wszystkim z tym państwem. W okresie Złotej Ordy i Ak Ordy językiem urzędowym był kipczacki. Język kazachski ukształtował się jako język narodowy w XV w.

Pod koniec lat 50. XIV w. Ułus Czagataidów rozpadł się na część zachodnią i wschodnią, które przekształciły się w niezależne państwa. Zgodnie z tradycją we wszystkich państwach mongolskich chanem mógł zostać jedynie Czingizid. Dlatego też, tworząc nowe państwo, emir plemienia Duglatów (Dulatów, Doglatów) Bołatszi (Puladczi) na jego czele postawił osobę, która jedynie formalnie miała sprawować swoje funkcje. Pierwszy chan Mogolistanu (Mogulistanu) objął władzę w Aksu w 1347/8 r. W skład Mogolistanu wchodziła część wschodniego Turkiestanu ${ }^{16}$. Należy zauważyć, iż granice Mogolistanu nie były stałe. Władza nad wschodnim Turkiestanem przechodziła wielokrotnie pomiędzy państwem Timurydów a Mogolistanem. Według Tarih-i-Raszidi Mirzy Muhammada Haidara, granice Mogolistanu były następujące: „Wschodni kraniec graniczy z ziemiami Kałmaków [...] Na północy granica przechodzi przez Kokcza-Tengir (jezioro Bałchasz), Bum i Karatał; na zachodzie Mogolistan graniczy z Turkiestanem i Taszkientem; na południu z wilajatem Fergana, Kaszgarem, Aksu, Czałyszem i Turfanem"17. Żetysu (południowo-wschodni Kazachstan) długo znajdował się w granicach Mogolistanu. W Mogolistanie głową państwa był chan, istniała Rada Starszyzny (Kuryłtaj), a tron był dziedziczny. W sprawowaniu władzy chanowi pomagał ułusbek (wyższy urzędnik administracyjny). Emirowie plemienia Duglatów przez długi okres kontrolowali chana i państwo Mogolistan. Ułusbek był wyznaczany spośród członków plemienia Duglatów, którzy mieli fundamentalne znaczenie dla powstania Mogoslistanu. Rozporządzenia chana potwierdzane pieczęcią, powtórnie były potwierdzane pieczęcią ułusbeka, które stawiano po pieczęci chana.

Mogolistan był państwowo-politycznym związkiem miejscowych turkijskich i sturkizowanych mongolskich plemion, które zlały się z miejscową ludnością i stworzyły wspólnotę etnopolityczną Mogołów (Mogułów). Wśród nich były plemiona Duglat, Kangły (Bekczik), Kireit (Kerej), Ujsun, Arkenut, Baari, Arłat, Barłas i inne. Znaczna część tych plemion weszła później w skład narodu kazachskiego ${ }^{18}$. Powstanie

${ }^{15}$ К. Ускенбай, Улусы первых Джучидов. Проблема терминов Ак-Орда и Кок-Орда, „Тюркологический сборник" 2005: Тюркские народы России и Великой степи, Алматы 2005.

16 Por. К.А. Пищулина,Казахское ханство во взаимоотношениях с Могулистаном и Шайбанидами в последней трети XV в., w: Казахстан в эпоху феодализма, Наука, Алма-Ата 1981, s. 96-123.

17 История Казахстана с древнейших времен до наших дней, в 5томах, t. 2, Атамура, Алматы 1997.

18 Por. К.А. Пищулина, „Бахр ал-асрар” Махмуда ибн Вали как источник по сочиально-экономической истории Восточного Туркестана XVI-XVП вв., w: Казахстан, Средняя и Центральная Азия в XV-XVШ вв., Наука, Алма-Ата 1983, s. 34-88. 
Mogolistanu było pierwszym krokiem ku ukształtowaniu się państwa narodowego i wpłynęło na proces tworzenia się narodowości kazachskiej.

Innym państwem, które powstało po rozpadzie Złotej Ordy i w wyniku osłabienia Ak Ordy, była Orda Nogajska. Był to feudalny związek koczowników, mający cechy państwa, który zajmował terytorium na północ od Morza Kaspijskiego i Jeziora Aralskiego, od Wołgi po Irtysz. Wśród ludności przeważały plemiona Mangitów, Kanratów, Najmanów, Argynów, Kanły, Ałszyn, Tama i inne. Ludność trudniła się przede wszystkim hodowlą bydła, prowadząc koczowniczy tryb życia. Istniało rozwinięte rzemiosło i architektura. Orda Nogajska była podzielona na ułusy, na których czele stali mirzowie ${ }^{19}$. Mirzowie byli podporządkowani bijom, a najwyższa władza spoczywała w rękach emira. Ze względu na to, iż chanem mógł zostać tylko potomek Czyngis-chana, nogajscy władcy tytułowali się emirami. W XVI w. migracja Nogajów na zachodni brzeg Wołgi przyczyniła się do podziału państwa, a najwyższą władzę u zachodnich Nogajów sprawował sułtan. Ułusy, plemiona i rody nieprzerwanie toczyły między sobą walki o pastwiska i władzę polityczną w Ordzie. Istniała gwardia władcy oraz drużyny udzielnych mirzów i bijów, które były ściągane na wypadek wojny. W wyniku niestabilnej sytuacji wewnętrznej, a także na skutek przyłączenia Chanatu Kazańskiego i Astrachańskiego do Rosji, Orda Nogajska zaczęła rozpadać się na kilka niezależnych części. Część Nogajów w późniejszym okresie przeniosła się do Imperium Osmańskiego, część znalazła się na terenach Rosji, a jeszcze inni rozproszyli się wśród Kazachów. Plemiona i rody, które zamieszkiwały Ordę Nogajską, miały bezpośredni wpływ na kształtowanie się narodu i państwowości kazachskiej.

We wspomnianych powyżej państwach powoli i w sposób nieprzerwany zachodził proces etnogenezy Kazachów. Powszechnie przyjęto, że współczesny naród kazachski dzieli się na trzy żuzy: Wielki (Starszy), Średni i Młodszy. Przedstawiciele złotego rodu, Czingizidowie, nazywają się tore, czyli tor jesi - mający prawo zasiadania na honorowym miejscu w jurcie od chwili urodzenia. Tore - arystokratyczny, uprzywilejowany stan w społeczeństwie kazachskim nie stanowi elementu struktury rodowo-plemiennej kazachskich żuzów. Wraz z nimi do przedstawicieli białej kości zaliczają się też hodżowie - potomkowie arabskich misjonarzy głoszących islam. Początki wszystkich kazachskich żuzów znajdują się na terytoriach ww. państw: Wielkiego (Starszego) $\dot{z} u z u$ w Mogolistanie, Średniego żuzu w Ak Ordzie i Młodszego $\dot{z} u z u$ w Ordzie Nogajskiej. Następnie weszły one w skład Chanatu Kazachskiego. Procesowi kształtowania się kazachskiego narodu towarzyszyło powstawanie państwowości kazachskiej. Kazachskie żuzy nawet po ukształtowaniu się narodowości

19 В.В. Трепавлов, История Ногайской Ордь, Восточная литература, Москва 2002. 
w większości zachowały w swoim składzie plemiona i związki plemienne, które zamieszkiwały dane terytorium za czasów istnienia ww. państw.

Należy zauważyć, że na skutek rozpadu Ak Ordy na terytorium dzisiejszego Kazachstanu w 1428 r. powstało Państwo Koczowniczych Uzbeków - Chanat Abułchaira (Abu al-Chajra), zajmujące ogromną przestrzeń między Ordą Nogajską na zachodzie, Mogolistanem na wschodzie, Chanatem Syberyjskim na północy i państwem Timurydów na południu. Jego Chanat nie był państwem scentralizowanym. Było podzielone na kilka etnoterytorialnych, etnopolitycznych grup, ułusów, na których czele stali Czungizidzi z różnych linii i elita plemion nomadów. Będąc potomkiem Szejbana, prowadził on krwawą i zaciekłą walkę z potomkami Dżocziego, którzy pretendowali do objęcia władzy w Uzbeckim Ułusie. Abu al-Chajr sprawował władzę przez 40 lat. Za swojego panowania umocnił państwo, przyłączył miasta Kazachstanu Południowego, ale niezadowoleni z jego silnych rządów potomkowie Barak-chana (poprzednika Abu al-Chajra) sułtani Dżanibek i Kerej (Keraj) wraz ze swoimi poddanymi (200 tys. osób) przenieśli się do Żetysu na terytorium Mogolistanu. Chan Mogolistanu Esen Buga przyjął ich i nadał im ziemię w miejscowości Kozybasy nad rzeką Czu. Plemiona, które odeszły z nimi, zaczęły być zwane z początku Uzbek-Kazachami, a później Kazachami (kazach oznacza wolny).

W roku 1465 utworzyli oni Chanat Kazachski. Po raz pierwszy w historii państwo kazachskie o takiej nazwie pojawiło się w $870 \mathrm{r}$. hidżry. Datę tę upamiętnił znany średniowieczny historyk Mirza Muhammad Haider Dulati - autor Tarih-i-Raszidi. W swoim dziele napisał: „Początek kazachskiego państwa - 870 rok hidżry” ${ }^{20}$. Po śmierci chana Abu al-Chajra w 1468 r. jego państwo rozpadło się. Głównymi przyczynami były konflikty personalne związane $\mathrm{z}$ podziałem terytorium oraz buntem przeciwko eksploatacji koczowników, który znalazł wyraz w przeniesieniu się ich na inne tereny. Sułtanowie Dżanibek i Kerej oraz ich zwolennicy powrócili do Ułusu Uzbeckiego, przejmując w nim władzę. Odsunięci od rządów potomkowie Abu al-Chajra z grupą plemion wtargnęli na terytorium Mawarannahr (rejon między rzekami Amu-darią i Syr-darią), podporządkowując sobie miejscową osiadłą ludność, wprowadzając polityczną nazwę Uzbek i kładąc podwaliny pod konsolidację współczesnego narodu uzbeckiego.

Powstanie Chanatu Kazachskiego nie było jednorazowym aktem, ale złożonym, długotrwałym i wieloaspektowym procesem, podczas którego zjawiska o charakterze politycznym i etnicznym zachodziły jednocześnie, bądź splatały się ze sobą. Z tego punktu widzenia Chanat Kazachski jest spadkobiercą państw wcześniej istniejących na terytorium dzisiejszego Kazachstanu. Konsekwentna badaczka Chanatu

20 Т.И. Султанов, Поднятые на белой кошме. Потомки Чингиз-хана, Дайк-Пресс, Алматы 2001. 
Kazachskiego K.A. Piszczulina zauważa, iż „źródłem i przyczynami powstania Chanatu Kazachskiego nie jest przeniesienie się Dżanibeka i Kereja, a gospodarczy, społeczny i polityczny rozwój ludności średniowiecznego Kazachstanu, włączając w to etniczną historię Kazachów"21. Po powstaniu swojego państwa Kazachowie umiejscawiali się prawie we wszystkich regionach współczesnego Kazachstanu, w czego konsekwencji zjednoczenie plemion kazachskich w jeden naród stało się faktem historycznym.

\section{Chanat Kazachski: forma państwa, władza i prawo}

Chanat Kazachski (1465-1847) ze względu na uwarunkowania polityczne powstał na terytorium Mogolistanu. Okres największej świetności Chanatu Kazachskiego przypadał na pierwszą część XVI w., szczególnie w okresie panowania Kasym-chana ${ }^{22}$. Za jego panowania liczba ludności Chanatu Kazachskiego po raz pierwszy osiągnęła milion osób. Jeżeli chodzi o strukturę administracyjną, to Chanat Kazachski za czasów Kasym-chana był podzielony na wilajaty (prowincje, w tłumaczeniu $\mathrm{z}$ arabskiego). Samoświadomość etniczna i poczucie przynależności do jednej społeczności wzmacniało się wraz z rozwojem państwowości kazachskiej. Kazachowie prowadzili głównie koczowniczy bądź półkoczowniczy tryb życia, ale obok tego istniały skupiska osadnicze, a nawet cywilizacja miejska, zapewniając symbiozę dwóch starych kultur. Należy zauważyć, iż zawsze w każdej społeczności nomadów pewna jej część prowadziła półkoczowniczy bądź osiadły tryb życia. Przeważnie tylko bogaci Kazachowie mogli koczować, a zbiedniałych, osiadłych na roli nazywano żatak. Władza i forma państwa były głęboko zakorzenione i ściśle odwoływały się do zasad „czingizmu" i separatyzmu w polityce wewnętrznej. Kazachscy chanowie byli czingizidami - bezpośrednimi potomkami Czyngis-chana, a próby przejęcia władzy przez nieczingizidów spotykały się z silnym oporem całego społeczeństwa. W państwach nomadów nie istniała silna hierarchia władzy, choć częściowo funkcjonował aparat przymusu. Koczownik, jeśli nie akceptował polityki rządzących, przenosił się na inne terytorium, zabierając ze sobą niewielką infrastrukturę materialną. Stanowiło to swojego rodzaju wyzwanie lub formę protestu. Słaba władza chanów nie była

\footnotetext{
${ }^{21}$ Ibidem.

22 Panowanie chanów w pierwszym okresie istnienia państwa: Kerej-chan 1465-1473, Żanybek-chan 1473-1480, Buryndyk-chan 1480-1511, Kasym-chan 1511-1518, Mamasz-chan 1518-1523, Tachir-chan 1523-1529, Bujdasz-chan 1529-1533, Togym-chan 1533-1538, Chak-Nazar-chan 1538-1580, Szygaj-chan 1580-1582, Tauekel-chan 1582-1598, Jesym-chan 1598-1628, Żangyr-chan 1628-1652, Zhanibek-chan 1652-1680. Por. http://www.besver.reklik.com/YEVcViAjZkZcUCZQfHd6dWBKXHdoc3B8ZX99.html
} 
przypadkowa. W kazachskiej społeczności mogła się ona opierać tylko na sytuacji etnopolitycznej, tj. na dobrowolnym sojuszu plemion i żuzów, podtrzymujących państwowość narodową.

Chanat Kazachski w XVI-XVII w. był faktycznie zintegrowanym organizmem politycznym, charakteryzującym się w większym lub mniejszym stopniu stabilnością. Przeżył czas powstania, rozkwitu i upadku, a w XVIII w. rozpadł się na oddzielne chanaty. Na czele każdego $\dot{z} u z u$ stał oddzielny chan. Terytorium chanatu niejednokrotnie zmieniało swoje granice w wyniku zmian sytuacji międzynarodowej, ale prawie zawsze pokrywało się z terenami, na których zamieszkała kazachska grupa etniczna - od rzek Irtysz i Karatał do rzek Syr-darii i Uralu; od gór Ałtaj i Tienszan do Morza Kaspijskiego i Jeziora Aralskiego.

Społeczność kazachska w XV-XVIII w. miała silnie zhierarchizowaną strukturę stanową. Stosunki między poszczególnymi stanami były regulowane prawem zwyczajowym i tradycją $a^{23}$. Na czele władzy państwowej stał chan - wybierany najwyższy władca. Na dworze chana urzędnicy [skarbnik, atabek (wychowawca następców chana) i inni] zajmowali się sprawami związanymi z bieżącym funkcjonowaniem chanatu. Tolengici - osobista gwardia chana - nie należeli do rodowej struktury społeczeństwa kazachskiego. Chan mógł być wybrany tylko z grona sułtanów (nierządzących potomków czingizidów). Przeważnie sułtani nie mogli podlegać karom cielesnym i nie podlegali sądowi bijów, osądzano ich na zjeździe bijów. Na tym samym poziomie jak Czingizidzi znajdował się hodża i saidzi - do nich należeli potomkowie proroka Muhammada, a także potomkowie jego wyznawców. Pozostała część społeczeństwa odnosiła się do kategorii kara-sujek (czarna kość), ale i ta grupa była podzielona.

Wiadomość o wyborze chana zawczasu docierała do wszystkich rodów kazachskich. Przyodziewano na tę okazję najlepsze szaty. Mężczyźni przyjeżdżali w pełnym rynsztunku bojowym, bez niego nie mieli prawa głosu. Zebranie otwierała modlitwa hodży, po czym przedstawiciel starszyzny udzielał głosu kandydatom. Każdy mógł wystąpić przed zebranymi. Zebrani wyrażali wolę poprzez odgłosy akceptacji bądź oburzenia. Zazwyczaj w święty dzień dla muzułman (piątek) rozpoczynał się rytuał „wyniesienia chana”. Na szczycie wzgórza rozkładano dywan, usadawiano na nim chana, a następnie trzy razy podnoszono go na dywanie nad swe głowy. Ogłaszano oficjalnie wybór chana. Zdejmowano z niego wierzchnią odzież i rąbano ją na drobne kawałki, które następnie zabierano jako relikwię. Odziewano go w zamian w biały chałat i kołpak. Bydło nowo wybranego chana rozdzielano między wszystkich zebranych, co symbolizowało, iż chan nie ma własnego majątku, a jego bogactwem jest bogactwo jego poddanych. W taki oto charakterystyczny sposób Kazachowie wybierali

${ }_{23}$ Т.И. Султанов, Чингиз-хан и Чингизиды. Судьба и власть, АСТ, Москва 2006. 
swojego chana. Chan miał prawa i obowiązki: zarządzanie terytorium, chronienie i zapewnianie bezpieczeństwa całemu krajowi, ogłaszanie wojny, zawieranie pokoju, prowadzenie negocjacji z innymi państwami; był najwyższym sędzią, stanowił prawo, ułaskawiał i decydował o życiu i śmierci. Znane są prawa Kasym-chana, Chak-Nazar-chana (1560-1580) i Jesym-chana (1565-1628), ale niestety, nie zachowały się one do naszych czasów w spisanej formie ${ }^{24}$.

W Chanacie Kazachskim stale funkcjonowała Rada (Chan kenesi), a także zwoływano Kuryłtaj, na którym podejmowano najważniejsze decyzje. Oprócz możnowładztwa w Radzie chana uczestniczyli bijowie (sędziowie) i batyrowie (wojownicy). Sprawy karne i cywilne podlegały bijowi. Był on nie tylko znawcą prawa zwyczajowego, ale też sztuki oratorstwa i był sprawnym mówcą. Bijowie występowali jako jednoczący ludność w państwo, a chan utożsamiał państwo. Prześladowanie bijów traktowano jako prześladowanie społeczeństwa. Dlatego też chanowie zawsze wsłuchiwali się w zdanie bijów. Z kolei batyr to silny duchem i ciałem człowiek, który ze sztuki wojny uczynił swoją działalność. Batyrowie to osobna grupa w społeczności nomadów, którzy aktywnie uczestniczą w sprawach państwowych, utrzymując ścisły związek z władzą chańską. W państwowości koczowników - Kazachów nie ma cech, które zazwyczaj charakteryzują państwo: władzy publicznej, opartej na określonej stanowej strukturze społecznej; centralnych i terenowych organów władzy wykonawczej; stałej armii, policji, aparatu sądowego i więzień. Wszystkie te atrybuty, charakterystyczne dla państwa klasowego, społeczności nomadów nie były potrzebne. W cywilizacji koczowników z właściwymi jej instrumentami w pełni mogą być wypełniane funkcje powyższych organów ${ }^{25}$. Przywódcy rodów i wodzowie plemion, bijowie wypełniają funkcje terenowych organów władzy, powszechne ruszenie zastępuje stałą armię, więzienia nie funkcjonowały.

W kazachskiej społeczności ziemia formalnie należała do rodu, a bydło było własnością prywatną. Podatki naliczano na terytoriach koczowniczych i rolniczych. Szurua - hodowcy bydła płacili ziaket (1/20 części pogłowia), a rolnicy - charadż (od 1/10 do $1 / 5$ zbiorów) i badż (podatek od obrotu towarami). Na wszystkich ciążył obowiązek utrzymywania administracji, wojska, prace melioracyjne, remont dróg itp. Za ukrytą formę opodatkowania można uznać sogum i sybagu, polegające na regularnym dostarczaniu bydła i produktów. Duchowieństwo muzułmańskie korzystało $\mathrm{z}$ immunitetu podatkowego.

24 Ibidem.

25 Por. С.З. Зиманов, К оценке казахского права в истории мысли, w: Древний мир права казахов, 2004, t. 2, s. 15-24. 
Za ojca kazachskiego prawa zwyczajowego uznaje się Tauke-chana (1680-1715/18), za którego rządów ostatecznie sformułował się system prawny w społeczeństwie kazachskim. Stworzył on wraz z Tolebi, Kazybekbi i Ajtekebi zbiór praw zwany Żety Żargy. Pierwszą istotną zmianę Tauke-chan wprowadził do systemu władzy. Rady bijów zostały przekształcone w organ społeczno-państwowy, który zajmował się bieżącymi sprawami. Obowiązywało prawo adat i szariat ${ }^{26}$, a funkcje sądownicze sprawowali bijowie - przywódcy rodów. Bi musiał cieszyć się nie tylko szacunkiem, ale też znać sztukę oratorstwa. Sąd bijów w swojej działalności kierował się podejściem humanitarnym, tak aby interesy obu stron zostały uwzględnione. W głębi kraju bijowie stanowili instytucję zarówno społeczną, jak i państwową, zapewniając przestrzeganie prawa w społeczeństwie. Wyjątkowo skomplikowane sprawy były rozstrzygane na zjeździe bijów. Bijowie za swoją pracę otrzymywali wynagrodzenie i rozmaite podarki. Możliwe, że zbiór praw Żety Żargy w sposób bezpośredni bądź pośrednio pochodzi od mongolskiego zbioru praw Jasa, który wprowadził Czyngis-chan. Mimo to Żety Żargy uznaje się za pradawny kazachski akt prawny. W skład Żety Żargy wchodziły następujące części: prawo ziemskie, prawo rodzinne i małżeńskie, prawo wojenne, postanowienia o procesach sądowych, prawo karne, kun (kara w postaci bydła), tj. prawo o kun, prawo o wdowach ${ }^{27}$. Stosowano zasadę domniemania niewinności. W sytuacji gdy nie było ewidentnych dowodów świadczących przeciwko oskarżonemu, bijowie rozstrzygali sprawę za pośrednictwem cieszących się autorytetem członków rodu, którzy pod przysięgą skazywali bądź uniewinniali oskarżonego. Przypominało współczesną instytucję sądu przysięgłych w państwach anglosaskich. Warto podkreślić jego długą historię, dojrzałość i sprawiedliwość. Można to uznać za jedną z istotniejszych przesłanek świadczących o samoregulacji społeczeństwa, co jest koniecznym atrybutem społeczeństwa obywatelskiego. Sąd bijów w społeczeństwie kazachskim stanowił specyficzny model sądu powszechnego. Należy zaznaczyć, iż prawo kazachskie Żety Żargy wyróżniało się swoją główną ideą - przede wszystkim ochrona interesów społeczeństwa. Było to prawo, które było odbierane jako sprawiedliwe i bezsporne, co znalazło odzwierciedlenie w światopoglądzie i mentalności społeczeństwa kazachskiego.

Po śmierci Tauke-chana kazachskie $\dot{z} u z y$ stanęły na czele poszczególnych chanatów. Tyko niektórym działaczom politycznym, jak Ałybaj-chanowi (1711-1781) czy Kene-chanowi (Kenesary-chan) (1802-1847), udało się czasowo zjednoczyć kazachskie chanaty. Po zgonie Kane-chana wojska rosyjskie zajęły Żetysu, a następnie południowe miasta Szymkent, Taszkient, Turkiestan i inne.

26 Ibidem.

27 С. Узбекулы, Хан Тауке и правовой памятник, Жеты Жаргы, Алматы 1998. 


\section{Kolonizacja chanatów kazachskich przez Imperium Rosyjskie}

Kolonizacja Kazachstanu rozpoczęła się jeszcze za czasów Piotra I. Wówczas to carska Rosja, wykorzystując krwawą wojnę Kazachów z Chanatem Dżungarskim (1635-1755), stopniowo wznosiła na tradycyjnie kazachskich ziemiach twierdze, w tym Jamyszewską (1716), Omską (1716), Żelezińską (1717), Semipałatyńską (1718), Ust-Kamienogorską, Koriakowską (1720). Materialne efekty tak prowadzonej polityki można określić jako bezpośrednie oznaki obcej interwencji w Chanacie Kazachskim. Militarny nacisk na osłabionych po 100-letniej (a nawet 200-letniej) wojnie z Dżungarami (Ojratami) Kazachów był główną przyczyną tzw. dobrowolnego przyłączenia. W latach 1731 i 1734 część Kazachów (Młodszy i Średni żuz) była zmuszona do przyjęcia zwierzchnictwa Imperium Rosyjskiego. Władze carskie myślały bardziej o rozszerzeniu swojego terytorium kosztem Kazachów niż o ich obronie przed agresją Dżungurów. W latach 60. XIX w. Rosja zagarnęła południowe regiony Kazachstanu. Do Imperium została przyłączona cała Azja Średnia. Następnie stopniowo znoszono władzę chanatu nad ludnością. Kazachowie utracili swoją państwowość. Jednak wyobrażenie o funkcjonowaniu poddaństwa u Kazachów różniło się od tego, jak powinno wyglądać poddaństwo według urzędników rosyjskich. Kazachscy chanowie, sułtanowie i społeczeństwo rozumiało poddaństwo jako stosunki patron-klient. Natomiast w carskiej Rosji utrzymywano silną hierarchiczną strukturę władzy. Gdy podejścia te zaczęły się wzajemnie wykluczać, narodziły się ruchy narodowowyzwoleńcze. Kazachowie niejednokrotnie występowali przeciwko polityce imperialistycznej. Po wojskowym opanowaniu ziemi kazachskiej władze rosyjskie przystąpiły do zmian w podziale terytorialno-administracyjnym ${ }^{28}$. Przy czym władze carskie nie liczyły się z lokalną specyfiką i różnicami kulturowymi. Przeprowadzane przez władze carskie reformy administracyjno-polityczne (1822, 1824, 1867-1868) zniszczyły tradycyjny system prawny i zarządzenia oraz umożliwiły osiedlanie na szeroką skalę rosyjskich przesiedleńców na terytoriach kazachskich, spychając ludność koczowników na mniej przydatne tereny. Uzyskawszy niekontrolowaną władzę nad większą częścią społeczeństwa, Rosja objęła swą polityką kolonizacyjną prawie wszystkie sfery. Taka polityka nie mogła jednak nie wywołać protestu ze strony społeczeństwa. Sprzeciwiający się polityce Imperium Rosyjskiego Kazachowie wybierali chanów (do końca lat 30. XX w., jeszcze w okresie władzy

28 К.К. Кенжебеков, Военно-наступательные аспекты присоединения Казахстана к России, Атамура, Алматы 2000. 
sowieckiej), byli im posłuszni i tę formę władzy uznawali za prawowitą. W ich działaniach przejawiał się duch wskrzeszenia niepodległego państwa.

\section{Zakończenie i wnioski}

W opracowaniu przedstawiono zarys historii państw, które istniały i rozwijały się dawniej na terytorium obecnego Kazachstanu. Poprzedzały one powstanie Chanatu Kazachskiego i stanowią o genezie wielowiekowej państwowości Kazachów. Autorzy postawili sobie za cel prezentację i analizę długiej historii oraz ciągłości państwowości kazachskiej, której korzenie sięgają daleko w przeszłość. W związku z tym, że w ostatnim czasie znów zaczęto podnosić kwestie związane z państwowością państw postsowieckich oraz następują kolejne przypadki politycznego kwestionowania historycznych wydarzeń i procesów dla uzasadniania aktualnych celów politycznych przez władze Rosji opracowanie w obrębie stosunków międzynarodowych ma również zwrócić uwagę na wygłaszanie nieprawdziwych i bezprawnych stwierdzeń oraz wysuwania przez niektórych polityków rosyjskich roszczeń wobec północnych ziem Kazachstanu, ale także innych terytoriów Azji Środkowej, Ukrainy czy republik bałtyckich.

Zdaniem autorów przedstawiona w opracowaniu analiza potwierdza, że:

- państwowość na terytorium Kazachstanu trwa co najmniej od epoki wczesnego żelaza, uwiarygodniając znane w literaturze przedmiotu analizy kształtowania się azjatyckiego typu państwa, mającego pewne odrębne cechy w porównaniu z instytucją państwa ukształtowaną w starożytnej Afryce czy Europie;

- mimo że część plemion, wchodzących w skład żuzów, przybyła w okresie średniowiecza, to społeczeństwo kazachskie jest autochtoniczne, o czym świadczą źródła archeologiczne, paleoantropologiczne, etnograficzne i pisane;

- państwowość kazachska zachowała formy rządów pochodzące z czasów tureckich kaganatów z okresu wczesnego średniowiecza i Imperium Czyngis-chana z czasów dojrzałego średniowiecza;

- jądrem Chanatu Kazachskiego i państwowości kazachskiej, oprócz Złotej Ordy (Ułusu Dżocziego), była także Ak Orda, Mogolistan, Orda Nogajska i Państwo Koczowników Uzbeków;

- powstanie Chanatu Kazachskiego było rezultatem złożonych, trwających wiele stuleci procesów o charakterze etnopolitycznym, społeczno-ekonomicznym i kulturowym, które doprowadziły do powstania i rozwoju instytucji państwa azjatyckiego typu; 
- specyficzną cechą kazachskiej państwowości w późnym średniowieczu było to, że rozwijała się ona pod rządami Czingizidów, ale na miejscowych, kazachskich etnicznych fundamentach;

- w Chanacie Kazachskim istniał swoisty aparat urzędniczy, prawo i inne atrybuty władzy, uwzględniające koczowniczy charakter gospodarki nomadów, sądy bijów były unikalną instytucją, pozwalającą zachować przez wiele stuleci dobrobyt i stabilność w społeczeństwie oraz unikalną państwowość narodowości kazachskiej;

- istnienie własnego państwa sprzyjało wytworzeniu się i ukształtowaniu kazachskiej narodowości, bowiem formuła kazachskiej państwowości oparta była na wartościach moralnych i kulturowych, a mniejsze znaczenie należy przypisać czynnikom ekonomicznym;

- po kolonizacji przez Imperium Rosyjskie naród kazachski przeciwstawiał się systemowi podatkowemu, systemowi administracyjno-terytorialnemu i innym atrybutom klasycznego państwa, ponieważ zawsze była mu bliższa formuła „Czingizid - władza - chanat”; w porównaniu z innymi państwami euroazjatyckimi władza Czingizidów w Kazachstanie i wśród Kazachów utrzymała się prawie do XX w., zapewniając państwowość i tradycyjną legitymizację władzy w społeczeństwie;

- powstanie Chanatu Kazachskiego w 1465 r. uznaje się za początek nowożytnej (w znaczeniu azjatyckim) państwowości Kazachstanu. Jest to zasadniczy powód ogłoszenia przez prezydenta Kazachstanu N. Nazarbajewa obchodzonej w 2015 r. 550. rocznicy kazachskiej państwowości ${ }^{29}$. Chanat miał wiele cech azjatyckiego państwa stanowego i nie stanowił jeszcze państwa narodowego w nowoczesnym, europejskim znaczeniu tego terminu. Terytorialnie został powołany w granicach współczesnego Kazachstanu, miał stabilny system władzy, dobre prawo i sprawny system sądownictwa oraz był podobny do innych organizmów państwowych istniejących na kontynencie azjatyckim, z którymi utrzymywał rozległe stosunki polityczne i handlowe.

29 Obchody 550-lecia państwowości kazachskiej w 2015 r. zaplanowano na szeroką skalę z udziałem gości zagranicznych. W programie przewidziano ponad 100 wydarzeń politycznych, kulturalnych i gospodarczych, wśród których jest również 20-odcinkowy serial TV pod roboczym tytułem „Chanat Kazachski”. 


\section{The state of Kazakhstan: history and present day}

The study attempts to present the most important facts related to the history of Kazakhstan. The paper also aims at introducing some theoretical remarks on the genesis and characteristics of states existing in different periods in Central Asia, particularly regarding Kazakh Khanate.

Keywords: Kazakhstan, state, Kazakh statehood, Kazakh Khanate, Asian type of state

\section{L'Etat du Kazakhstan: hier et d'aujourd'hui}

L'étude tente de présenter les faits les plus importants liés à l'histoire du Kazakhstan. Le document présente également une réflexion sur la genèse et les caractéristiques des états existants en Asie centrale dans le passé, en particulier Kazakh Khanate.

Mots-clés: le Kazakhstan, l'état, Kazakh Khanate, le type asiatique de l'Etat

\section{Казахская государственность: история и реальность. Вклад в теорию государства}

В связи с растущей пропагандистской агрессией России, ставящей под сомнение и обесценивающей институциональные проявления существования в прошлом других стран, кроме России, на постсоветском пространстве, целью авторов настоящей статьи является распространение документально потвержденных знаний о некоторых проявлениях многовековой казахской государственности - знаний далеких от попыток мистификации и фальсификации исторических событий и процессов в Центральной Азии. Одновременно, цель состоит также в том, чтобы представить результаты теоретических выводов в области учения о государстве, определяющих истоки и характеристику государственных организмов, появившихся в обширных районах Центральной Азии в различные периоды истории цивилизации. Исследование доказывает, что государственность на территории Казахстана начинается как минимум с эпохи раннего железа, подтверждая известные в литературе анализы формирования государства азиатского типа, у которого есть некоторые отличительные особенности по отношению к институтам 
государства созданного в древней Африке или Европе. Образование Казахского ханства в 1465 г. было результатом многовековых, сложных, этнополитических, социально-экономических и культурных процессов, которые привели к созданию и развитию институтов государства азиатского типа. В Казахском ханстве существовал своебразный бюрократический аппарат, закон и другие атрибуты власти, учитывающие кочевой характер экономики номадов, а суды биев являлись уникальным институтом, позволившим сохранить в течение многих веков благоденствие, стабильность общества и уникальную государственность казахского народа. Все это подтверждает, что ханство как государство имело стабильную систему власти, хорошую и эффективную правовую и судебную системы и было похоже на другие государственные организмы существовавшие на азиатском континенте, с которыми поддерживались обширные политические и торговые связи.

Ключевые слова: Казахстан, государство, государственность Казахстана, Казахское ханство, государство азиатского типа 